\section{Equal Justice}

Eric Rakowski, 385 + xii pages, Oxford, 1991, Clarendon Press, $£ 40.00$.

Professor Rakowski begins his book with a quote from Aristotle's Politics: 'All hold that justice is some kind of equality'. His own account of an egalitarian conception of distributive justice in this outstanding book ranks alongside the pioneering work recently done in this area by writers such as John Rawls and Ronald Dworkin.

Rakowski's answer to the question of how scarce resources are to be shared around he calls 'equality of fortune', and his defence of this notion takes up the first half of the book. Like G A Cohen, Rakowski believes that the essence of egalitarianism lies in evening out the effects of 'brute' bad luck, that is, ill fortune which is not the result of risk incurred by the agent. Inequalities arising from chance require a redistribution of resources, and 'resources' here include physical and mental capacities. Ideally, each should start life with equally valuable resources, subject to two caveats: there is some presumption in favour of allowing gifts and bequests to children; and great sacrifices cannot be called for from the more fortunate. Rakowski's is not merely a 'starting-gate' theory. Equality of fortune as a general ideal along with a stress on the importance of personal autonomy - requires the establishment of various insurance schemes, and the details of these are developed carefully in the book.

Theories of justice are often set in opposition to utilitarianism, and here Rakowski's thesis looks particularly strong: why should someone who has already been dealt a bad hand by fate suffer yet more at the hands of morality on the ground that he or she will be an inefficient consumer of resources? Like Rawls, Rakowski offers us a view of 'justice as fairness'.

Rakowski closes Part I of the book with a chapter on whether transferable organs or blood should be seen as resources subject to redistribution. $\mathrm{He}$ argues that they should be, and that in certain circumstances compulsory extraction of, for example, blood might be justified. This would be unusual, however, if his recommendation that post mortem extractions be the norm were adopted.

Part II of the book defends an account of strict liability which may be useful to those interested in medical negligence. In particular, Rakowski's attack on the idea that tort law is to be understood in wealth maximising terms is such that this view must henceforth be consigned to the dustbin of philosophical history.

In Part III, Rakowski returns to the more straightforwardly medical ethical issue of the allocation of life-saving resources. He argues that numbers are relevant in life-saving decisions, but not because it is objectively better if, other things being equal, a larger group survives. Rather, we are each required now to form an intention to save the larger group in any such case, since this is in the interest of all.

Rakowski dedicates a chapter to considering whether particular characteristics of persons, such as age or moral character, should influence choices between lives. His subtle discussion concludes that only (i) large differences in age and (ii) the individual's responsibility for his or her plight are relevant. He ends the book by defending a rights-based view against, in most circumstances, killing one being to benefit others.

I disagree with some of Rakowski's negative arguments, acute as they are; but his sophisticated and humane account of justice is among the most powerful and persuasive I have read. His discussions of medical ethical questions will be the starting point for those who address these questions in future. This is a book that deserves to be - and no doubt will be - taken very seriously indeed.

ROGER CRISP, Fellow in Philosophy, St Anne's College, Oxford.

\section{AIDS: an Epidemic of Ethical Puzzles}

Edited by the Hastings Center, USA, 187 pages, Dartmouth, 1991,

Gower Academic Publishing Group, $£ 32.50$ hc.

The acquired immune deficiency syndrome, with its undertones of sexuality and a pervasive fear of contagion, has been the catalyst for a revolution in professional ethics. The issues of patient autonomy, the conduct of placebo control trials, the rights of confidentiality, informed consent, death with dignity, and the obligations to provide care for individual health care workers are all explored in this recent collection of papers from the
Hastings Center.

What struck me most forcibly, on reading this book, was the major shift in ethical perceptions during the AIDS epidemic. The early paternalistic pronouncements from professional bodies have been modified in the light of experience and have lost some of their lofty tone. It is helpful in the present difficulties of the National Health Service to recognise that in Britain there has long been a consensus of an entitlement to health care by all and a less well expressed view of the obligation of individual health-care workers to provide such treatment. Such a consensus does not exist in the United States where health care is not freely available to all and professional bodies jealously cherish the right of doctors to act as independent contractors and to refuse to provide health care. Human immunodeficiency virus infection is slowly altering this perception with many States enacting anti-discriminatory legislation.

The other fascinating aspect of this collection of papers is a thoughtprovoking review of the obligations and opportunities of researchers in the Third World. The changes in ethics occurring in different social and cultural situations are clearly? expounded.

As a lay reader I am always left vaguely disappointed that this sort of book does not provide a few simple rules which would guide me in day-today ethical decisions. I am, however, reassured when I discover that people who have made the study of ethics their lifetime's work face the same difficulties. This book is a fascinating historical account of the ethical dilemmas produced by the AIDS epidemic and makes a thoughtprovoking change from the average textbook, although it is rather expensive at $£ 32$.

BRIAN GAZZARD Consultant Physician and AIDS Co-ordinator, Westminster Hospital, Dean Ryle Street, Horseferry Road, London SWIP 2AP.

\section{Family Rights: Family Law and Medical Advance}

Edited by Elaine Sutherland and

Alexander McCall Smith, 135 pages, Edinburgh, 1991, Edinburgh Press, $£ 25.00$. 
Recent scientific developments in human reproduction have significant and wideranging implications for traditional notions of 'the family' and family rights. Sutherland and McCall Smith's collection of essays provides a useful survey of the main legal and ethical issues raised by modern medical technology. Medical advances have changed relationships within the family as well as the relationship between the family and society; the response of family law to these changes is explored by the authors of these essays in an interesting and thought-provoking way.

The potential of modern medicine to affect profoundly the family and family law is illustrated by the changing nature of family rights. McCall Smith questions whether there is anything left of parental rights. In a coherent and succinct way, he shows how, within the area of treatment of minors, parental rights have been subordinated to the child welfare principle as greater medical self-determination of the child is recognised by the law. The diminishing importance of parental rights is further revealed in Cusine's more specific discussion of the issue of consent in relation to the provision of contraceptives to minors and the sterilisation of mentally handicapped children.

Two of the essays concern the important ethical and legal questions encompassing the new reproductive technologies. Dickens examines the family issues raised by the technologies and deals carefully with many of the legal problems. However, I felt more thorough discussion of the moral and ethical concerns would have placed greater weight on the overall conclusion that opposition to such scientific advances rests on conservative ideologies of family relations. In her balanced analysis of the ethical and moral arguments surrounding surrogacy, Sheila McLean expands upon the idea that opposition to these techniques is founded in antiquated attitudes about women's reproductive capacities and conduct. Her belief that there is nothing inherent in surrogacy to justify interference with a person's involvement in such arrangements extends to surrogacy for payment. The moral objection to the financial element in surrogacy as amounting to 'babyselling' is perhaps too easily answered by the suggestion that payment be denoted for the service rendered. However, the realistic observation that, inevitably, surrogacy will continue leads to the conclusion that the law should address, not ignore, the problems of surrogacy, minimise exploitation, combat entrenched attitudes about gender roles and provide essential regulation.

This slim volume supplies the reader with a variety of interesting subjectmatter. There is analysis of the family's role in life and death decision-making for incompetent patients, as well as a thought-provoking exploration of the fundamental ethical and legal questions raised increasingly in genetic counselling. Further, Elaine Sutherland's discussion about whether we should regulate pregnancy in order to protect the fetus highlights the theme in the book that the family reflects the individualistic ethos of modern society. In considering intervention in both preand post-conception contexts, she advocates that certain restrictions may justifiably be imposed on pregnant women. I agree with her conclusion that any regulation must be in conjunction with counselling, ante-natal care and financial support but my concern lies in the absence of concrete proposals about how such restrictions could be put into practice without disproportionate regulation of women's freedom.

As a general observation, I felt the overall tone and coherence of the book could have been enhanced by a different ordering of the essays. Having said that, I enjoyed this interesting and thoughtful analysis of the changes wrought on the family and family law by modern medicine, hitherto a neglected subject. It will be of particular value to lawyers and ethicists and will provide essential material for the continuing debates surrounding modern technology.

JENNY L URWIN, Faculty of Law, University of Manchester.

\section{Mapping the Code. The Human Genome Project and the Choices of Modern Science.}

Joel Davis, 294 pages, Sussex, 1991, John Wiley and Sons, $£ 14.95$.

The application of recombinant DNA technology to medical research has already produced enough success stories to suggest that this new field will make a major impact on clinical practice in the future. One of the most newsworthy items from its short life is the human genome project, that is the idea of building up a complete map of our hundred thousand or so genes in their locations along our chromosomes.

As with much of the 'new biology' the ideas behind the genome project are not new but the powerful analytical tools of recombinant DNA are allowing them to be exploited in a novel fashion. In 1927 J B S Haldane reasoned that if it were possible to map 50 or more inherited 'characters' they could be used as markers for predicting whether children would carry genes for important disorders such as Huntington's Disease. The idea is beautifully simple. Supposing we want to follow the progress of a particular gene through a family and have no way of identifying it. The idea is to find a gene with a product which we can identify and which is linked to the gene that we are looking for. If the two are so close together that they always stay together through successive generations we now have a 'handle' on the gene we can't identify; if our marker is inherited so must be the gene that is closely linked to it. The same principle can be used to 'find' genes for diseases for which the cause is unknown; if we know where our marker is located the gene we are after must be close by. DNA technology has now provided us with an abundance of markers which should enable us to generate a linkage map of the human genome and, ultimately, a physical map, that is its precise nucleotide base sequence. This will undoubtedly enhance our ability to isolate genes for single gene disorders and help us to understand the complex polygenic systems which underlie conditions such as diabetes, coronary artery disease, cancer and the psychoses.

Joel Davis's book is one of several that address the complex issues raised by the human genome project. Like its fellows it starts by explaining recombinant DNA technology in terms which are comprehensible to the nonspecialist. It goes on to outline the background to the project and its political aspects, describes some of the science behind it and ends by raising some of the ethical issues which may follow from its exploitation.

Presumably in an attempt to catch the readers attention the first chapter describes a series of scenarios under the heading of FUTURELINE. For example, FUTURELINE 2, subheaded THE GENEBUM, describes a 19-year-old woman who is unable to obtain employment because 